\title{
Accident Mitigation and Management Measures for NH-44(India) from Khannabal to Qazigung in Jammu-Kashmir
}

\author{
Mouamil Khan, Sandeep Singla, Sualiheen Ahmad
}

\begin{abstract}
Accidents are not natural but they are caused is a common cliché in the area of traffic safety. Thus, if accidents are caused, surely the reasons responsible for them could be identified and appropriate remedial measures developed and implemented to the extent feasible. This study lays emphasis on the safety analysis and accident studies of National Highway -1A(NH-44) on the 24 Km long stretch of road from Khanabal to Qazigund which is the main connecting link of Kashmir valley to Jammu and the rest of the country. As such this road is subjected to heavy vehicular traffic carrying passengers and goods and is the main strategic road of the state of Jammu and Kashmir State, it is one of the busiest and dangerous roads of the country. The problem of traffic flow is very acute due to complex flow of vehicular traffic, presence of mixed traffic along with pedestrians. Traffic accidents lead to loss of life and property. Also the stretch under study is subjected to rough weather conditions particularly during the winters. The primary objective of this study is to carry out the safety analysis of National Highway-1A(NH-44) on the $24 \mathrm{Km}$ long stretch of road from Khanabal to Qazigund and provide a solution to the traffic accidents which occur on this $24 \mathrm{Km}$ long stretch of road from Khanabal to Qazigund. The National Highway-44 (formerly known as NH 1A) connecting Kashmir Valley to the rest of the country has always been susceptible to accidents.
\end{abstract}

Index Terms: Accident Mitigation, Jammu and Kashmir, Counter Measures, Priority Index, highway.

\section{INTRODUCTION}

As per the Commission for Global Road Safety (2009), road traffic accidents kill an estimated 1.3 million people and injure 50 million people per year globally [1]. Further, the global road fatalities are forecasted to reach 1.9 million by 2020. With rapid increase in industrialization, motorization and multilane highways in India; the casualties due to accidents on the roads are increasing alarmingly year by year [2]. The dominance of road transport will continue in India as it has in the rest of the world. The share of the movement of both passengers and goods is expected to increase further in the coming years with the full implementation of the current road development programs being undertaken in the country. Studies of the relationship between gross domestic product (GDP) per capita, growth of motor vehicles and road fatalities have shown that fatality rate increases as GDP increases at relatively low levels of GDP per capita, but then start to decline with continued GDP growth. The peak position on this inverted U-shaped curve is not, however,

Mouamil Khan, Department of Civil Engineering,RIMT University, Chandigarh,India.

Sandeep Singla,, Department of Civil Engineering,RIMT University, Chandigarh,India.

Sualiheen Ahmad,Department of Civil Engineering,National Institute of Technology ,Srinagar, India immutable [3]. At present more than 600,000 accidents occur annually with about 147,000 people losing their life in these accidents. Besides fatalities, nearly 600,000 people suffer injuries in road accidents which lead to lifelong misery for the victims and their families. Figure 1 shows the increase in traffic fatalities in last 50 years. Road Safety Study can ensure that various safety deficiencies in road are reviewed so that these can be taken care at appropriate stage of road design or operation in a cost effective way [4].

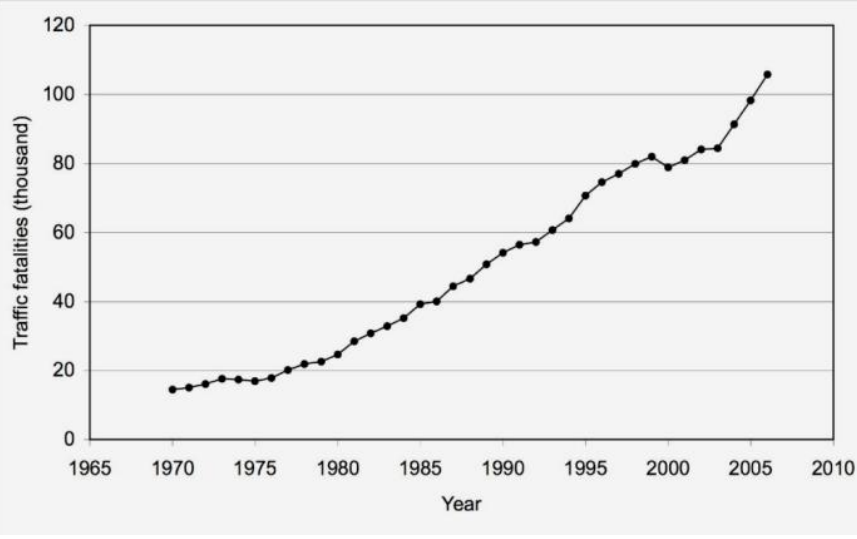

Fig 1: graph showing the increase in accidents in India since $1965-2010$

Kashmir region is suffering from poor infrastructure regarding transportation and regional connectivity problems. National Highway 1A supports the flow of movement of people, goods and other consumables, supporting the business activities in the region [5] [6]. The Khanabal to Qazigund stretch of national highway carries heavy traffic and lacks the necessary transportation facilities and infrastructure, ultimately making it prone to road traffic accidents and creating a major problem for the common people in this region. Jammu and Kashmir ranks second across India in the tally of road accidents per 10000 vehicles with an average of over 900 deaths every year from 2015-2018 according to Union Ministry of Road Transport and Highways and the NH-44 contributes to a large chunk of these accidents.

The objective of this research project is to analyses and develop recommended countermeasures for solving the traffic accidents on the National Highway-1A stretch from Khanabal to Qazigund. The project's research approach is based on 1) a study of accident data collected from the concerned police stations, 2) evaluation of black spots, 3) providing countermeasures to mitigate accidents at black spots. The basic methodology which we are intending to follow is to concentrate only on the black 
spots (located from the data) instead of conducting the survey of the whole stretch. The basic approach for black spot identification is characterized by applying statistical analysis and mapping based on the historical accident records of the road network. Once black spots have been identified, accident data are analyzed in order to find common pattern in accidents. A visit of the black spot site is usually part of the process of analysis.

\section{METHODOLOGY}

The National Highway-1A is the main connecting link of Kashmir with rest of the country. Therefore, it is subjected to vehicular traffic throughout the year. The weather conditions are rough for many months. Hence the condition of the road should be exquisite and up to the safety standards. But it is not so because a lot of accidents have been reported from the highway including the road stretch under study.

The violence that killed thousands in Kashmir during the turbulent 1990s has eased; now killer roads are taking their toll. Daily police report about road accidents present a horrible scenario; and almost every week we see newspaper headlines screaming about casualties being inflicted by road accidents across the Kashmir valley. Despite the recurrence of accidents, mostly because of bad roads and lack of proper traffic regulation measures, the government thinks nothing beyond the announcement of token relief for mishap victims.

\section{Data Collection}

Primary data collection involves the following parameters which are collected after site visit based on IRC codes [7] [8] [9] [10] [11].

1) Design Speed 2) Horizontal Curves 3) Super-elevation 4) Sight Distance 5) Vertical Grades. 6) Carriageway width 7) Shoulder width. The data in table 1 shows the various primary parameters associated with each accident prone site. The current methodology also involves collection of secondary data from accident records from traffic police Jammu-Kashmir. Data on traffic accidents in the study road stretch i.e., (Khanabal to Qazigund) were collected from First Information Report (FIR) of two police stations: Qazigung and Anantnag. It is tabulated in table 2.

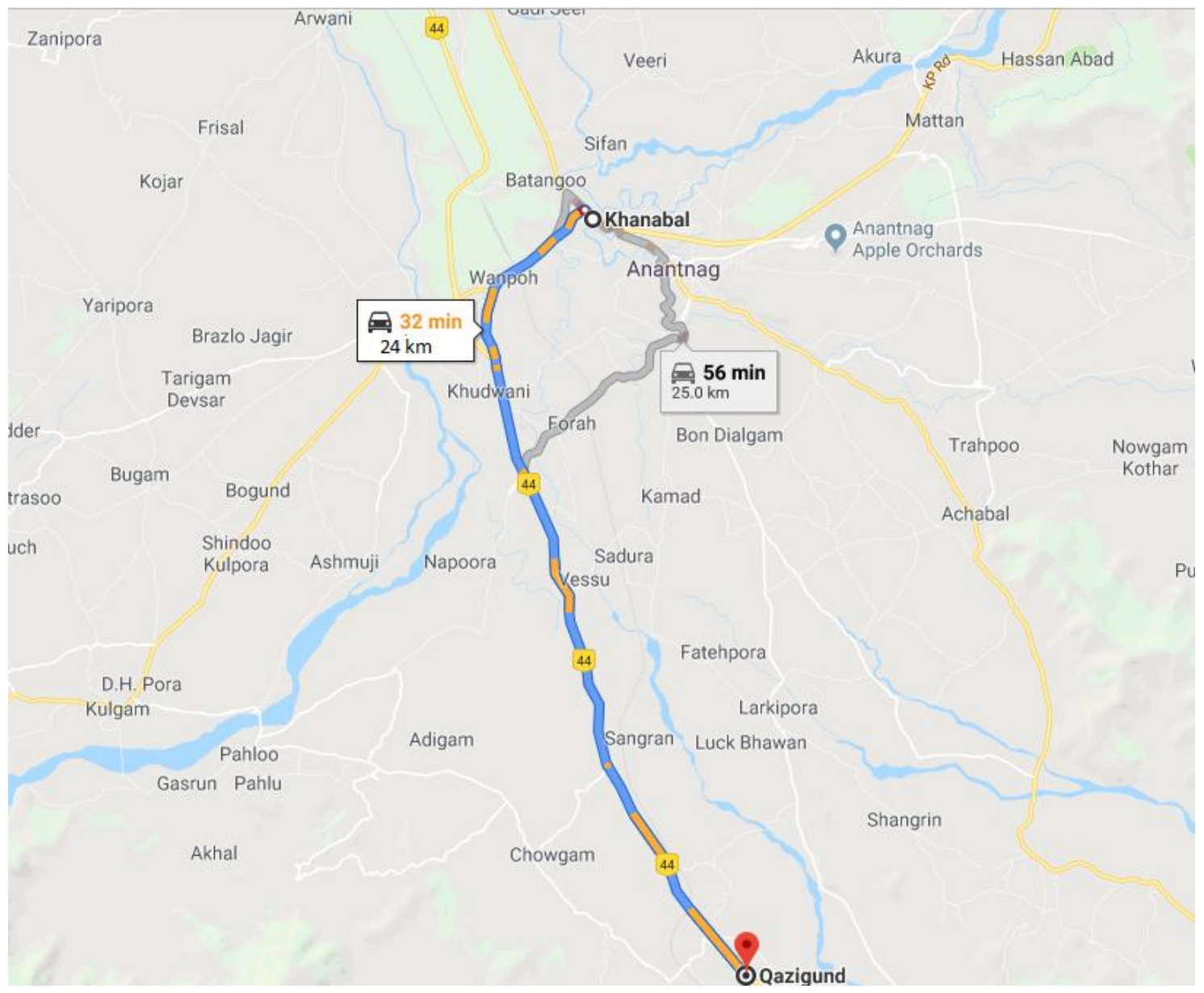

Fig 2: Location map of study stretch

Table 1 - Data Collected from Various Accident Prone Sites. 
International Journal of Innovative Technology and Exploring Engineering (IJITEE) ISSN: 2278-3075, Volume-8, Issue-9S, July 2019

\begin{tabular}{|c|c|c|c|c|c|c|}
\hline Sno & Place & $\begin{array}{l}\text { R.D } \\
(\mathrm{KS})\end{array}$ & Radius (M) & $\begin{array}{l}\text { Super Elevation } \\
\qquad(\%) / \\
\text { Cross Slope }(\%)\end{array}$ & $\begin{array}{l}\text { Sight Distance } \\
\text { (M) }\end{array}$ & $\begin{array}{c}\text { Carriageway } \\
\text { Width(M) }\end{array}$ \\
\hline 1 & $\begin{array}{c}\text { KHANABAL } \\
\text { CHOWK }\end{array}$ & $\mathrm{O}$ & STRAIGHT & 2.5 & 400 & 12 \\
\hline 2 & WANPOH & 3.1 & STRAIGHT & 2 & 30 & 9 \\
\hline 3 & GASSIPORA & 3.9 & 78.94 & 7.2 & 62 & 9.1 \\
\hline 4 & ALSTOP & 4.3 & 130 & 3 & 90 & 8.2 \\
\hline 5 & MIR BAZAR & 7.1 & STRAIGHT & 2.5 & 150 & 8.2 \\
\hline 6 & Nipora & 8.8 & 100 & 7 & 200 & 8.2 \\
\hline 7 & VESSU & 10 & $\begin{array}{c}\text { Curved } \\
\mathrm{C}_{1}=53 \\
\mathrm{C}_{2}=63 \\
\mathrm{C}_{3}=67.3\end{array}$ & $\begin{array}{l}E_{1}=7.6 \\
E_{2}=5.6 \\
E_{3}=6.3\end{array}$ & 35 & 8.2 \\
\hline 8 & SESMAN & 13 & $\begin{array}{c}\text { Curved } \\
\mathrm{C}_{1}=99.22 \\
\mathrm{C}_{2}=260 \\
\mathrm{C}_{3}=125\end{array}$ & $\begin{array}{c}E_{1}=6.5 \\
E_{2}=4 \\
E_{3}=5\end{array}$ & 210 & 8.2 \\
\hline 9 & Bonigam & 14 & Straight & 2.5 & 120 & 9 \\
\hline 10 & Badragund & 15.2 & STRAIGHT & 2 & 200 & 8.5 \\
\hline 11 & Levdora & 16.5 & STRAIGHT & 2.5 & 220 & 8.2 \\
\hline 12 & Qazigund & 19.5 & STRAIGHT & 2.5 & 80 & 8.2 \\
\hline
\end{tabular}

Table 2: Abstract of accident data 


\begin{tabular}{|c|c|c|c|c|}
\hline \multirow{2}{*}{ Road stretch } & \multirow{2}{*}{$\begin{array}{l}\text { Number of } \\
\text { accidents }\end{array}$} & \multicolumn{2}{|c|}{ No. of persons } & \multirow{2}{*}{$\%$ accidents } \\
\hline & & Died & Injured & \\
\hline Vesso & 11 & 06 & 12 & 5.37 \\
\hline Gassipora & 11 & 00 & 18 & 5.37 \\
\hline Mirbazar & 13 & 03 & 13 & 6.34 \\
\hline Sesman & 07 & 03 & 11 & 3.41 \\
\hline Wangund & 06 & 01 & 05 & 2.9 \\
\hline Nipora & 15 & 00 & 18 & 7.31 \\
\hline Bonigam & 11 & 02 & 09 & 5.37 \\
\hline Levdora & 14 & 01 & 11 & 6.8 \\
\hline Malpora & 07 & 03 & 18 & 3.41 \\
\hline Ujroo & 08 & 00 & 13 & 3.9 \\
\hline Main market Qazigund & 12 & 02 & 11 & 5.85 \\
\hline Hospital Qazigund & 04 & 00 & 04 & 1.95 \\
\hline Badragund & 08 & 01 & 12 & 3.9 \\
\hline Shampora & 05 & 00 & 09 & 2.4 \\
\hline Zig NH-1A & 04 & 01 & 05 & 1.95 \\
\hline Dalwatch & 06 & 00 & 03 & 2.9 \\
\hline Tool post & 10 & 02 & 10 & 4.88 \\
\hline Glass tower NH-1A & 03 & 00 & 03 & 1.47 \\
\hline Palpora & 07 & 00 & 12 & 3.41 \\
\hline Yatraniyas NH-1A & 02 & 00 & $\mathrm{O} 4$ & 0.9 \\
\hline Damjan & 06 & 03 & 06 & 2.9 \\
\hline Alstop & 03 & 01 & 13 & 1.46 \\
\hline Khanabal & 11 & 03 & 5 & 5.37 \\
\hline Harnag & 04 & 01 & 00 & 2 \\
\hline
\end{tabular}

\section{Analysis of Collected Data}

It is well known by highway engineers and traffic police that road accidents tend to cluster together at certain locations, commonly termed "accident blackspots". At 
such sites, it is likely that some aspect of highway design, layout and state of road or traffic control is a contributory factor in the accident occurrence. As a consequence, it has been well established that considerable safety benefits may result from the application of appropriate road engineering or traffic management measures, which are accident countermeasures [12].

The data collected for secondary sources is analyzed for the identification of unsafe locations and that collected from primary site surveys is used in ranking of accident prone locations and identifying causes of accidents.

\subsection{Accidents by Vehicle Type}

The variations for study stretch are represented in Figures 3-6. It can be seen from the figures that trucks and tata-sumos are vehicle types that contribute heavily in accidents. Also pedestrian involvement is very heavy. Almost 17 percent of the fatalities are of pedestrians. Two wheelers, tippers (half-body trucks) and goods carrier tempos/ auto-rickshaws also contribute heavily.

\subsection{Accidents by Type of Accident}

The number of accidents occurring by accident types like overturning, head-0n-collision rear-ends collision, side swipe and hit $\&$ run also varies considerably. Figure 7 shows the number of accidents by accident type occurring in Khanabal to Qazigund stretch of National Highway-1A.

1.3 Accidents by Severity

The severity of accidents in terms of number of minor injuries, grievous injuries or fatalities also varies for locations and accidents. Figure 12 shows the accident severity for data of study stretch.

\subsection{Accidents by Frequency}

The frequency of accidents by the time of year varies considerably. This may be because of variations in road condition, traffic volume and visibility during these months due to varying weather conditions (high temperature, snowfall, fog etc.).

After data collections, data were analyzed statistically by graphs and pie charts. Figures 3-13

\section{Identification of Accident Prone Locations/Black Spots}

This involves treating a specific site or short length of road by looking for clustering by accident-type, rather than identifying sites on the basis of total accident numbers only. Particular accident-types can be identified, for example, there may be cluster of right-angle accidents or run off road accidents. Based on the secondary data collected from the police stations and the subsequent analysis twelve (12) locations are identified along the $24 \mathrm{~km}$ road stretch that have higher than expected frequency of some common pattern of accidents. In general, the various factors that because accidents can be broadly categorized into road related, vehicle related and driver related. In this study, an attempt is made to implement mainly the road-related factors for predicting the accident prone points/stretches (black spots) on roads and thus help in identifying the required remedial measures.

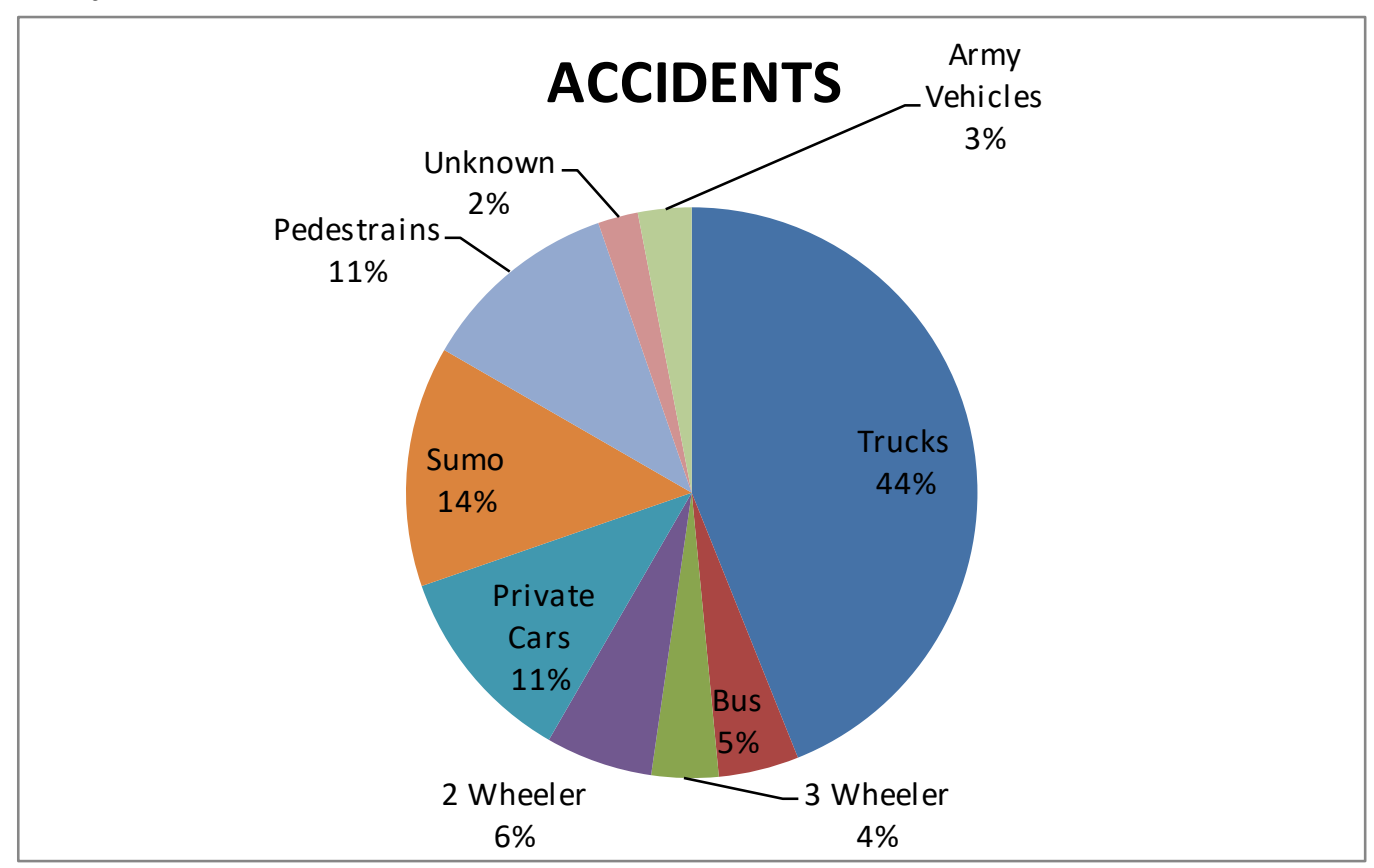

Fig 3-Vehicle Involvement in Accidents in Study Stretch (2015-2017) 


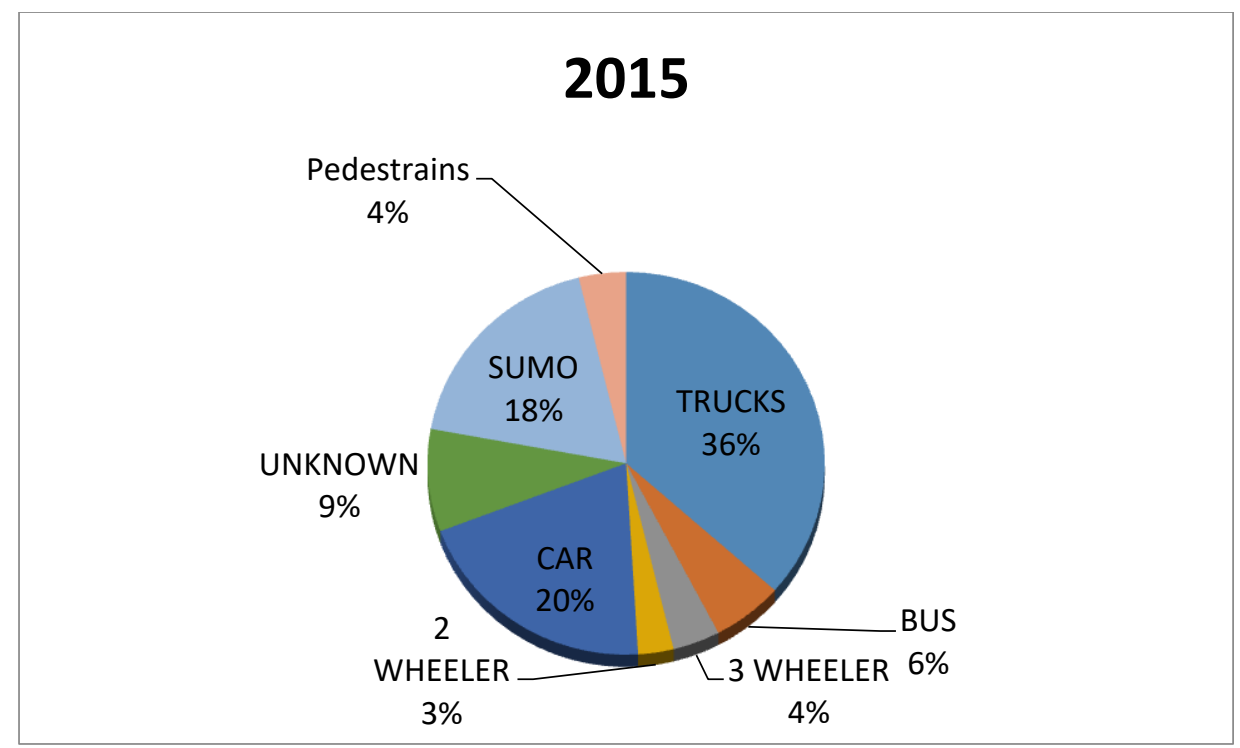

Fig 4-Vehicle Involvement in Accidents in Study Stretch (2015)

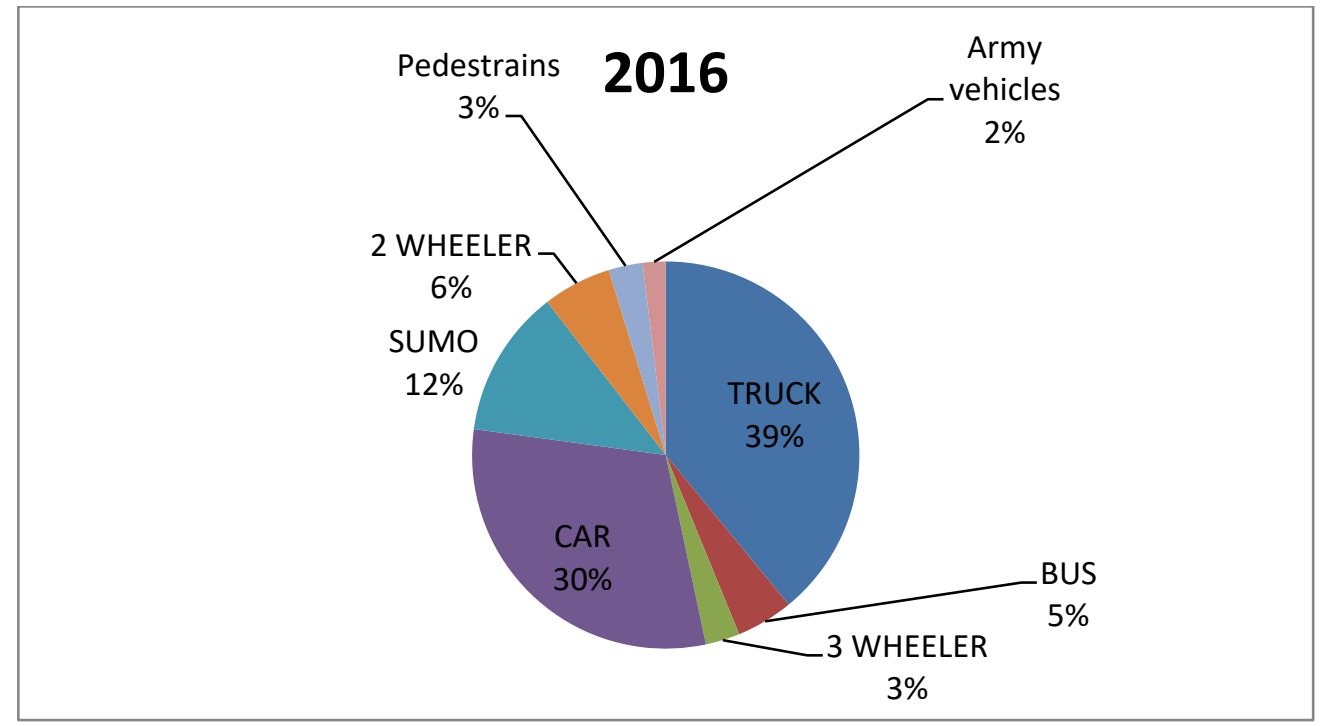

Fig 5- Vehicle Involvement in Accidents in Study Stretch (2016)

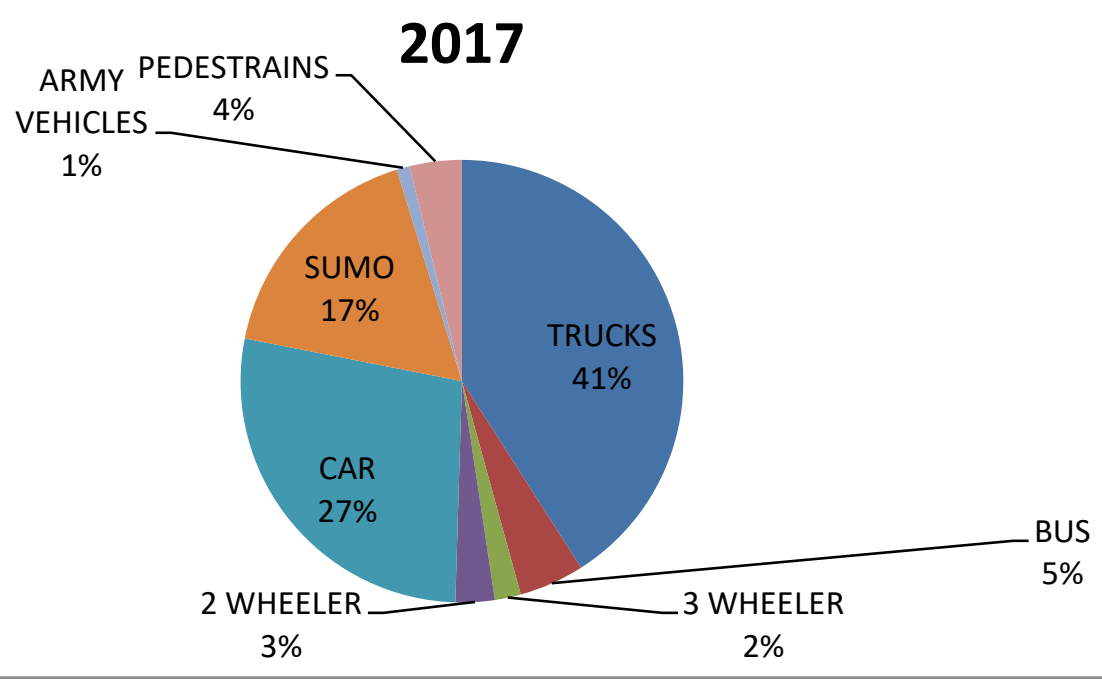

Fig 6- Vehicle Involvement in Accidents in Study Stretch (2017) 


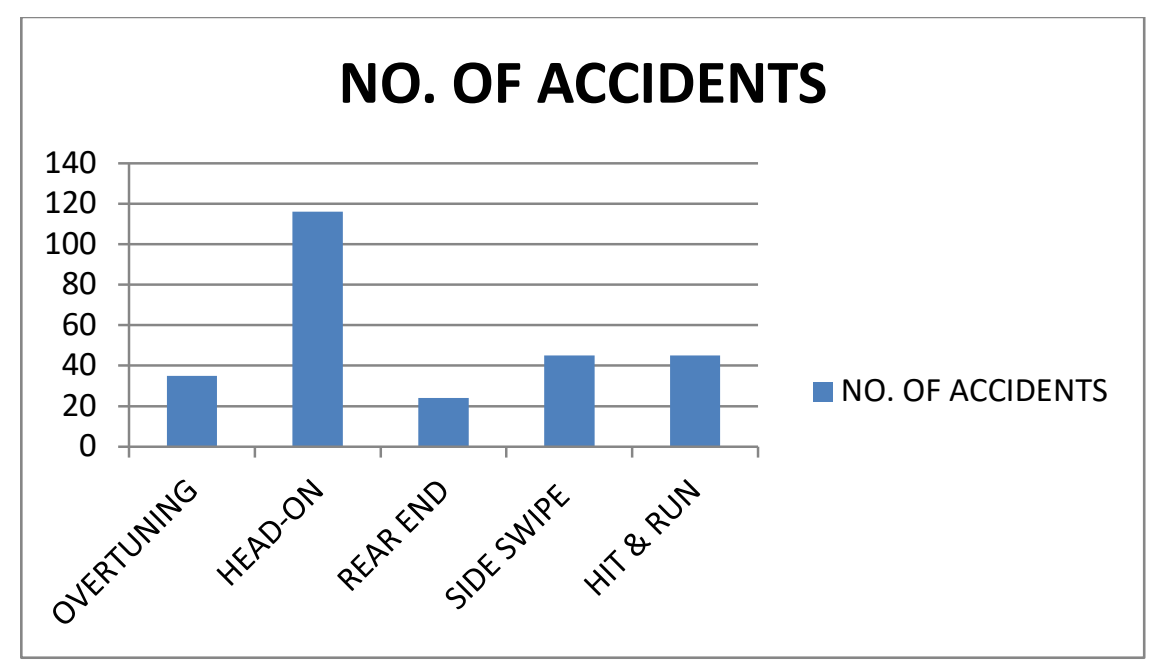

Fig 7- Type of Accidents occurring under study stretch

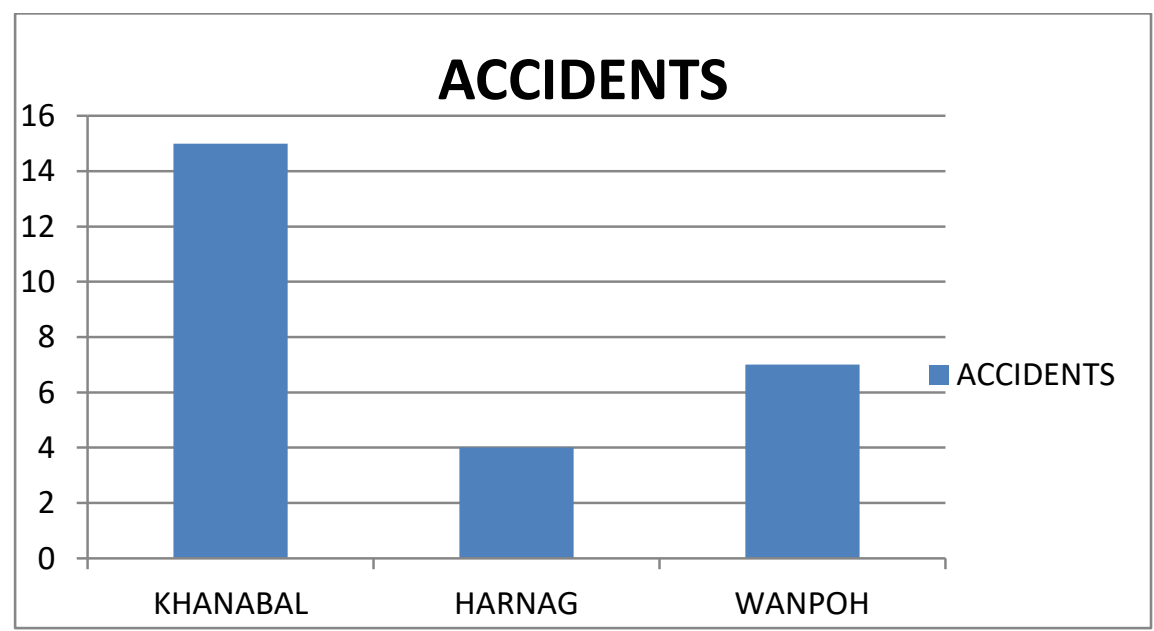

Fig.8- Accidents on study stretch in Anantnag P/S area (2015-2017)

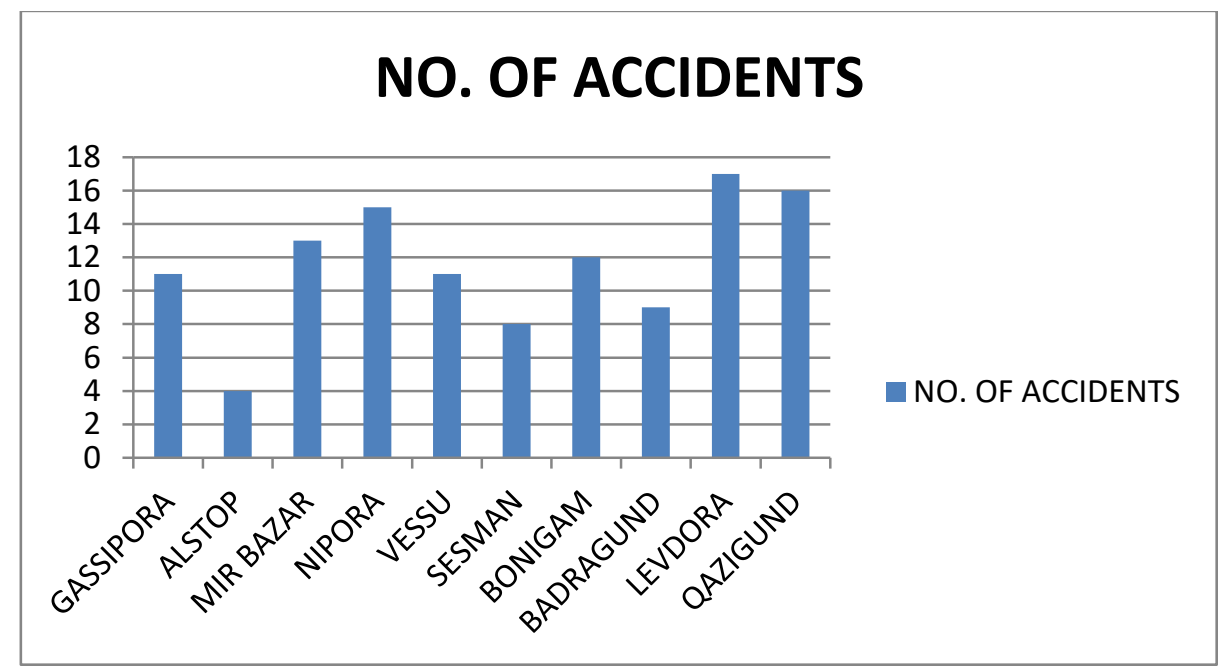

Fig.9- Accidents on study stretch in Qazigund P/S area (2015-2017) 


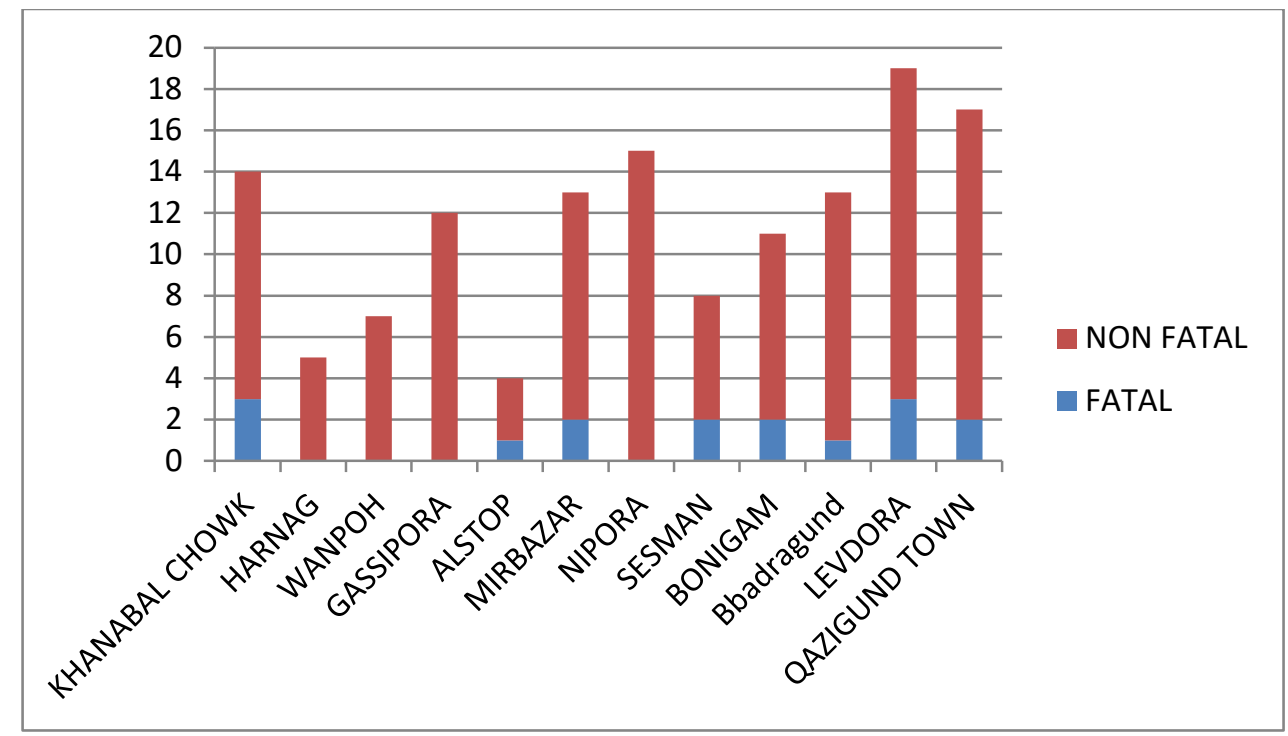

Fig 10- No. of accidents in the study stretch at blackspots from 2015-2017

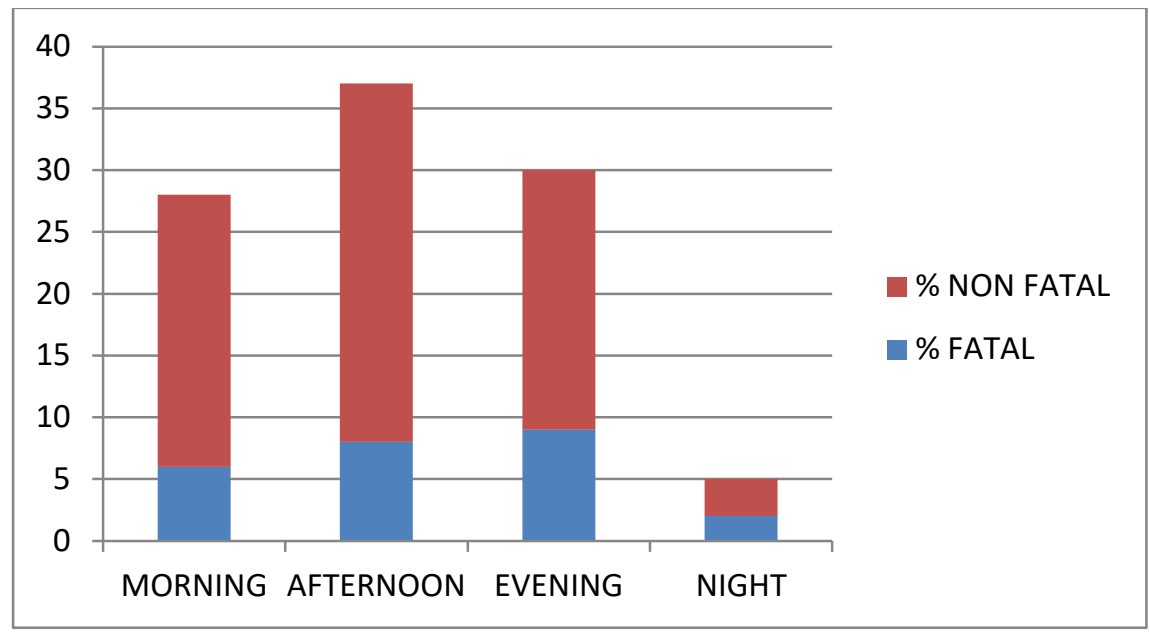

Fig 11 Time wise accident distribution on NH study stretch.

\section{NUMBER OF DEATHS/INJURIES}

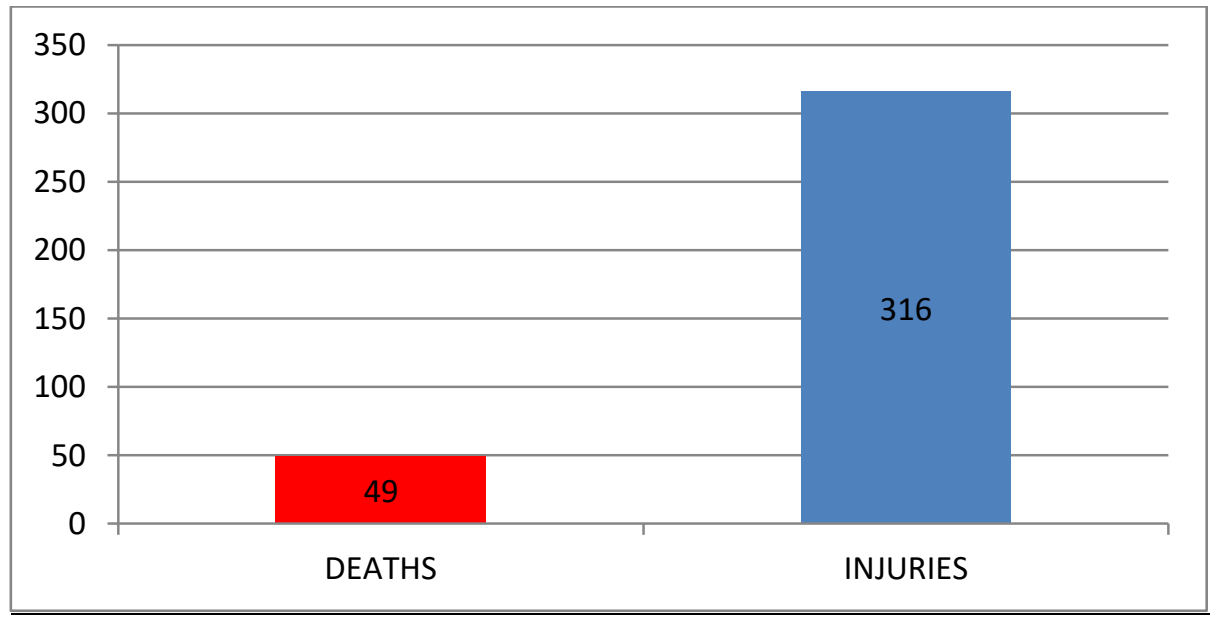

Fig 12- Number of deaths/injuries on study stretch from 2015-2017 


\section{WEATHER CONDITION}

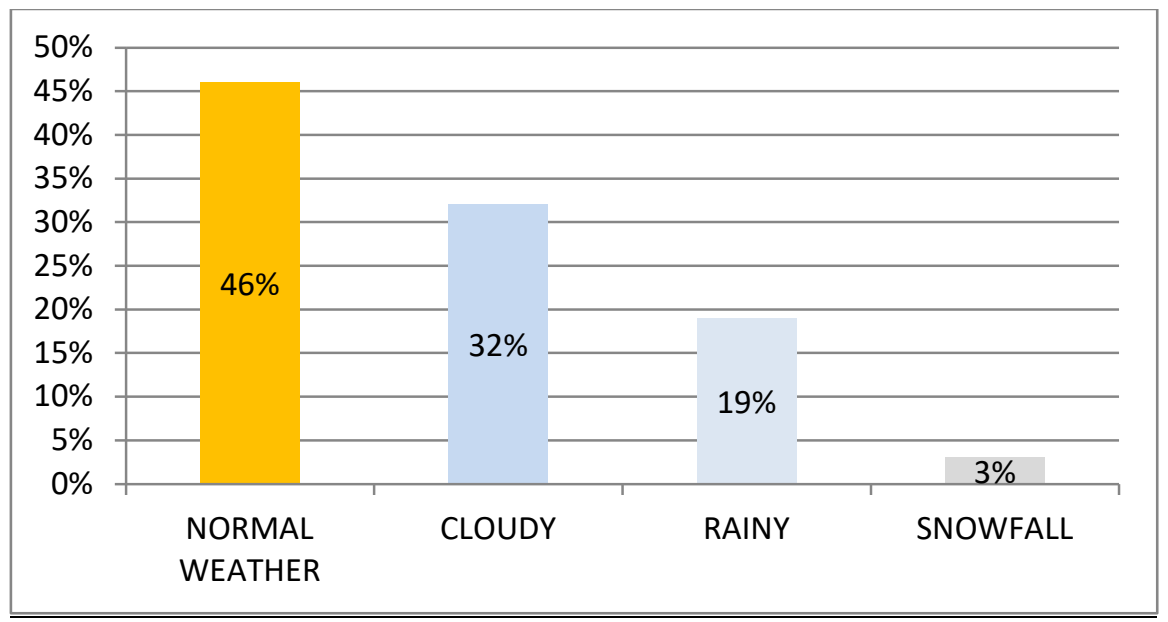

Fig. 13 Percentage of Accidents on study stretch according to weather (2015-2017)

\section{Prioritization of Identified Black Spots for Treatment}

Ranking of Black Spots/ Accident Prone Locations and Prioritization involves assigning suitable weights to different factors so as to achieve a desired result. In this method, the various factors, which tend to influence the occurrence of accidents on roads, are assigned weights on a scale of 0-10 in such a manner that the factors which tend to increase the probability of the accidents have lower weights. In order to prioritize roads for occurrence of accidents, the various factors considered and the weights assigned to them are given in Table 3. The final weight assigned to each road link is obtained by adding all the individual weights and normalizing the value using maximum weight (in this case
110) that can be assigned. The values of weights of different factors for black spots and their accident prone levels (APLs) are given in Table 3 .

Thus road links/spots with high final weight are less prone to accidents than the road links/spots with low final weight. The classification of roads for occurrence of accidents based on final weights is done using the classification scheme given in Table 3.

Total weight $($ Accident prone level $(\mathrm{APL}))=(\Sigma$ Individual Weights) $\times 100 /$

Table 3- Factors used in Accident Location Prioritization and their Weights

\begin{tabular}{|c|c|c|c|}
\hline Code & Factors affecting occurrence of accidents & $\begin{array}{l}\text { Possible variations in } \\
\text { weight }\end{array}$ & $\begin{array}{l}\text { Weight } \\
\text { assigned }\end{array}$ \\
\hline A & $\begin{array}{l}\text { Relative severity rates } \\
=(\text { No. of severity at specific site/ highest no of severity at a site } \\
\text { in study stretch }) \times 10\end{array}$ & $\begin{array}{l}10-9 \\
9-8 \\
8-7 \\
7-6 \\
6-5 \\
5-4 \\
4-3 \\
3-2 \\
2-1 \\
1-0\end{array}$ & $\begin{array}{l}1 \\
2 \\
3 \\
4 \\
5 \\
6 \\
7 \\
8 \\
9 \\
10\end{array}$ \\
\hline B & Approximate number of vehicles per day & $\begin{array}{l}\text { Less than } 1000 \\
\text { Less than } 2500 \\
\text { Less than } 5000 \\
\text { Greater than } 5000\end{array}$ & $\begin{array}{l}10 \\
7 \\
4 \\
1\end{array}$ \\
\hline $\mathrm{C}$ & Width of the road & $\begin{array}{l}\text { Single lane } 3.75 \mathrm{~m} \\
\text { Two lanes without raised } \\
\text { kerns, } 7.0 \mathrm{~m} \\
\text { Two lanes with raised } \\
\text { kerbs, } 7.5 \mathrm{~m} \\
\text { Intermediate carriageway } \\
\text { Multi-lane pavements }\end{array}$ & $\begin{array}{l}2 \\
4 \\
6 \\
8\end{array}$ \\
\hline
\end{tabular}




\begin{tabular}{|c|c|c|c|}
\hline $\mathrm{D}$ & Drainage facilities provided & $\begin{array}{l}\text { Good } \\
\text { Satisfactory } \\
\text { Poor } \\
\text { No Drainage }\end{array}$ & $\begin{array}{l}10 \\
7 \\
4 \\
1\end{array}$ \\
\hline $\mathrm{E}$ & Surface condition of the pavement & $\begin{array}{l}\text { Concrete } \\
\text { WBM } \\
\text { Other Bituminous } \\
\text { Surface Painted } \\
\text { Bad surface }\end{array}$ & $\begin{array}{l}10 \\
8 \\
6 \\
4 \\
2\end{array}$ \\
\hline $\mathrm{F}$ & Frequent vehicle type on the road & $\begin{array}{l}\text { Carts } \\
\text { Two Wheelers } \\
\text { Car/Sumo } \\
\text { Mixed } \\
\text { Bus /Truck }\end{array}$ & $\begin{array}{l}10 \\
6 \\
4 \\
3 \\
2\end{array}$ \\
\hline G & Presence of shoulders & $\begin{array}{l}\text { Yes (good) } \\
\text { Poor shoulder } \\
\text { No shoulder }\end{array}$ & $\begin{array}{l}10 \\
6 \\
4\end{array}$ \\
\hline $\mathrm{H}$ & $\begin{array}{l}\text { Presence of edge obstructions like } \\
\text { advertising hoardings, trees etc. very } \\
\text { close to the road }\end{array}$ & $\begin{array}{l}\text { Yes } \\
\text { No }\end{array}$ & $\begin{array}{l}4 \\
10\end{array}$ \\
\hline I & Provision of median barriers, signs or markings & $\begin{array}{l}\text { Yes } \\
\text { No }\end{array}$ & $\begin{array}{l}10 \\
4\end{array}$ \\
\hline $\mathrm{J}$ & $\begin{array}{l}\text { Presence of ribbon development near } \\
\text { Roads }\end{array}$ & $\begin{array}{l}\text { Yes } \\
\text { No }\end{array}$ & $\begin{array}{l}4 \\
10\end{array}$ \\
\hline $\mathrm{K}$ & Road Geometric & $\begin{array}{l}\text { Straight stretch with no } \\
\text { junction } \\
\text { Straight stretch with } \\
\text { junction } \\
\text { Flat curve } \\
\text { Sharp curve no junction } \\
\text { Sharp curve with junction }\end{array}$ & $\begin{array}{l}10 \\
5 \\
7 \\
3 \\
1\end{array}$ \\
\hline
\end{tabular}

Table4-. Assignment of Weights to Accident Prone Locations

\begin{tabular}{|c|c|c|c|c|c|c|c|c|c|c|c|c|}
\hline Place & $\mathrm{A}$ & $\mathrm{B}$ & $\bar{C}$ & $\mathrm{D}$ & $E$ & $F$ & $\bar{G}$ & $\mathrm{H}$ & $\mathrm{I}$ & $\mathrm{J}$ & $\mathrm{K}$ & APL \\
\hline Khanabal & 5 & 1 & 6 & 7 & 6 & 3 & 6 & 4 & 4 & 4 & 5 & 46.36 \\
\hline Wanpoh & 10 & 1 & 4 & 7 & 6 & 3 & 6 & 4 & 4 & 4 & 5 & 49.09 \\
\hline Gassipora & 10 & 1 & 4 & 4 & 6 & 3 & 4 & 4 & 4 & 10 & 3 & 48.18 \\
\hline Alstop & 9 & 1 & 4 & 4 & 6 & 3 & 10 & 10 & 4 & 4 & 7 & 56.36 \\
\hline Mir Bazar & 5 & 1 & 4 & 1 & 6 & 2 & 6 & 4 & 4 & 4 & 5 & 38.18 \\
\hline Nipora & 10 & 1 & 4 & 10 & 6 & 2 & 4 & 10 & 4 & 10 & 7 & 60.90 \\
\hline Vessu & 7 & 1 & 4 & 7 & 6 & 2 & 4 & 4 & 4 & 4 & 1 & 40.00 \\
\hline Sesman & 5 & 1 & 4 & 4 & 6 & 2 & 6 & 10 & 4 & 10 & 3 & 50.00 \\
\hline Bonigam & 7 & 1 & 4 & 4 & 6 & 3 & 6 & 4 & 4 & & & 43.63 \\
\hline
\end{tabular}




\begin{tabular}{|l|l|l|l|l|l|l|l|l|l|l|l|l|}
\hline Badragund & 9 & 1 & 4 & 7 & 6 & 3 & 10 & 4 & 4 & 4 & 5 & 51.81 \\
\hline Levdora & 9 & 1 & 4 & 4 & 6 & 3 & 6 & 10 & 4 & 4 & 5 & 50.9 \\
\hline Qazigund Town & 7 & 1 & 4 & 4 & 6 & 3 & 10 & 4 & 10 & 4 & 1 & 49.09 \\
\hline
\end{tabular}

Table 5 - Accident Location Prioritization Scheme

\begin{tabular}{|l|l|}
\hline \multicolumn{1}{|c|}{ Final Weight (\%) } & \multicolumn{1}{c|}{ Accident Prone Level (APL) } \\
\hline $80-100$ & Very Low \\
\hline $60-80$ & Low \\
\hline $40-60$ & Medium \\
\hline $0-40$ & High \\
\hline
\end{tabular}

Thus ranking of sites was done on the basis of their APL values and the name of sites in order of their ranking is as under: -

1) Nipora. 2)-Alstop 3) Badragund 4). Levdora5) Sesman 6) Wanpoh. 7) Qazigund Town. 8) Gassipora. 9)Khanabal 10). Bonigam. 11) Vessu. 12) Mir Bazar.

\section{RESULTS and RECOMMENDATIONS}

The collected data of the whole stretch from Khanabal to Qazigund was thoroughly analyzed and particular sites were prioritized. Based on the APL values we chose two sites namely 1) NIPORA and 2) ALSTOP for in depth and specific site analysis as shown below.

\section{NIPORA}

Site conditions:

I. Two lane straight road followed by an abrupt curve in embankment.

ii. Carriage way width is $8.2 \mathrm{~m}$.

iii. Shoulder width less than $1 \mathrm{~m}$.

iv. Radius of curve is $100 \mathrm{~m}$.

v. Drainage condition is good.

vi. Camber is $2.2 \%$

vii. Super elevation of curve is $7 \%$.

viii. Traffic conditions:

a) Traffic volume is 1184 PCU's per hour

b) Mixed traffic flow conditions.

c) Operating speed of vehicles:

Table 6- operating speed of vehicles on Nipora stretch of $\mathrm{NH}$

\begin{tabular}{|c|c|c|c|}
\hline $\begin{array}{c}\text { Vehicle } \\
\text { type }\end{array}$ & $\begin{array}{c}\text { Maximum } \\
\text { Speed } \\
(\mathrm{kmph})\end{array}$ & $\begin{array}{c}\text { Minimum } \\
\text { speed } \\
(\mathrm{kmph})\end{array}$ & $\begin{array}{c}\text { Average } \\
\text { speed } \\
(\mathrm{kmph})\end{array}$ \\
\hline LMV & 84 & 45 & 60 \\
\hline SMV & 35 & 30 & 32 \\
\hline HMV & 80 & 38 & 54 \\
\hline
\end{tabular}

Safe speed on curve:

Assuming super elevation counteracts centrifugal force only,
$\mathrm{E}=(0.75 \mathrm{~V}) 2 / \mathrm{gR}$

$0.07=(0.75 \mathrm{~V}) 2 / 9.81 \times 100$

$\mathrm{V}=11.06 \mathrm{~m} / \mathrm{s}$

Or $\mathrm{V}=40 \mathrm{kmph}$

Causes of accident:

I. High speed of vehicles on straight stretch of road.

II. No signs and road markings.

III. Drop down shoulders.

IV. No overtaking sight zone present.

\section{ALSTOP}

Site conditions (shown in fig 14):

i. Two lane road having a curve.

ii. Width of carriage way $=7.7 \mathrm{~m}$

iii. Bad drainage conditions.

iv. Ribbon development along the road side having petrol pump nearby.

v. Surface condition of road is rough having number of pot holes.

vi. Parking width varies from 6.7 to $8.9 \mathrm{~m}$.

vii. Traffic conditions:

a) Traffic volume 1197 PCU's per hour

b) Mixed Traffic flow conditions.

c) Operating speed:

$\mathrm{SMV}=27 \mathrm{kmph}$

$\mathrm{LMV}=70 \mathrm{kmph}$

$\mathrm{HMV}=37 \mathrm{kmph}$

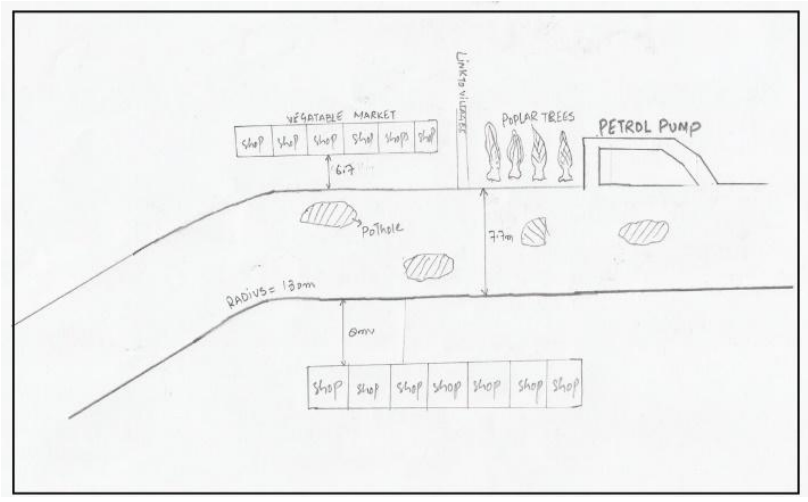

Figure 14- Sketch Of Alstop Stretch

Geometric features of road

Sight distance required for $70 \mathrm{kmph}=100 \mathrm{~m}$

Published By:

Blue Eyes Intelligence Engineering

\& Sciences Publication 


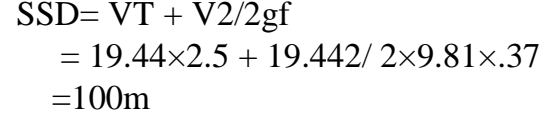

Safe speed for curve:

Assuming super elevation counteracts centrifugal force only,

$$
\begin{aligned}
& \mathrm{E}=(0.75 \mathrm{~V}) 2 / \mathrm{gR} \\
& 0.03=(0.75 \mathrm{~V}) 2 / 9.81 \times 130 \\
& \mathrm{~V}=8.24 \mathrm{~m} / \mathrm{s} \\
& \text { Or } \mathrm{V}=30 \mathrm{kmph}
\end{aligned}
$$

The Analysis shows that the following are the main reasons for the accidents occurring on the black spots [13] [14].

1) High speed of vehicles on straight stretch of road. 2)No signs and road markings. 3)Drop down shoulders. 4) No overtaking sight zone present. 5)Poor road surface conditions. 6)Sight restrictions caused by the parked vehicles. 7)No separate parking lanes. 8)Inadequate sight distance at petrol pump junction 9)Reduction of the carriage way capacity due to the parked vehicles.10) Poor Design of Road Geometrics like sight distance 11) Inappropriate gradient 12) Lack of Pedestrian crossings.

Keeping all these factors in view, we recommend the following countermeasures [15] [13].

\section{Countermeasures}

1) At Nipora, shifting of electric poles and transformer away from the carriage way should be done. Road marking and proper signage should be provided. Guard rails should be provided and the shoulder width increased.

2) At Alsop, we recommend the Separation of parked vehicles by providing parking lanes and removal of poplar trees near the petrol pump obstructing sight distance. We also recommend repairing of pot holes and restricting speed up to 30kmph.Truck Bays should be provided.

3)At Khannabal Chowk, we recommend providing pedestrian crossing near college area and also road markings and signs. Provide guard rails and restrict speed up to 40 kmph.

4)At Wanpoh, the speed should be restricted up to 30 $\mathrm{km} / \mathrm{hr}$ conflicting points by channelizing the intersection and providing pedestrian crossing. Installation of traffic signals could also be done alternatively. 5) At Sesman and Vessu, speed at the curve should be restricted to $35 \mathrm{kmph}$.

6)At Levdora and Bonigam, pedestrian crossings should be provided.

7) At Qazigund Town, speed should be restricted to 40 $\mathrm{kmph}$. Also, road widening could be done at the curves.

\section{CONCLUSION}

In conclusion, traffic police records and newspaper records of the stretch gave an insight into the magnitude of the problem of accidents on the stretch from Khannabal to Qazigund. On analyzing the data, it was clear that there are many black spots where corrections need to be done. After site visits at the black spots, the primary data was collected and thereby analyzed further. This made it clear that many geometric aspects like shoulder width, SSD, curve length, gradient of the road need to be corrected. Also, traffic management on the road needs to be undertaken to stop future accidents from taking place and mitigating any risk associated with the same.

\section{REFERENCES}

[1] M. D., "Road accidents in India," ATSS research, 2009

[2] T. O. S. M. F. M. Mohan D, "Road safety in India: challenges and opportunities.".

[3] S. SK., "Road traffic accidents in India: issues and challenges.," Transportation research procedia.,2017

[4] R. M., "National statistics of road traffic accidents in India.," Journal of Orthopedics, Traumatology and Rehabilitation., 2013.

[5] f. kallu, "www.greaterkashmir.com," [Online].

[6] S. Bukhari, "www.risingkashmir.com," 2016. [Online].

[7] IRC-53, Road Accident Forms A-1 and A-4, National Highway Authority of India(NHAI), Ministry of Surface Transport, New Delhi: The Indian Road Congress(IRC) publication, 1982.

[8] IRC-66-1976, Recommended practice for Sight Distance on

Rural National Highways, New Delhi, The Indian Road Congress(IRC), New Delhi, 1976.

[9] IRC-73-1980, Geometric Design Standards for Rural(Non-Urban) Highways, New Delhi: Indian road congress, 1980.

[10] IRC-SP-44-1996, Highway safety Code, The Indian Road Congress(IRC) special publication44, New Delhi, Indian Road Congress, 1996.

[11] IRC-SP-55-2001, Guidelines on safety in road construction zones, National Highway Authority of India(NHAI), Ministry of Surface Transport, New Delhi: The Indian Road Congress(IRC) publication, 2001.

[12] S. C. Khanna, Highway Engineering,9th edition, Mahavir Marg, NemChand \& Brothers, Roorkee, 2011.

[13] A. P. Mehar R, "A systematic approach for formulation of a road safety improvement program in India.," Procedia-Social and Behavioral Sciences.,2013.

[14] R. GK., "Road Traffic Safety Management in India-Analysis-Exploring Solutions.," International Journal pr Application or Innovation in Engineering \& Management (IJAIEM).,2013.

[15] A. J. J. W. Ombisa BA, " Causes and Mitigation Measures for Road Traffic Accidents in Public Service Vehicles in Kenya.," 2010.

\section{AUTHORS PROFILE}

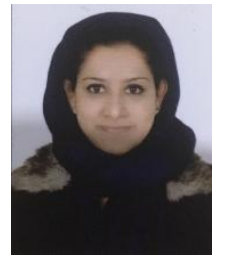

Mouamil KhanB-Tech Civilfrom Islamic University of Science and Technology Awantipora.Pursuing M-Tech-Infrastructure Technology and Managementfrom RIMT University Punjab. She has workedas Senior Project Engineer in Cottage Industries Exposition, Kashmir with expertise in various kinds of building works.She has also taken part in more than three seminars about construction of roads and the new advancements in the same.Her interests include Construction Technology,Surveying,Highway Engineering and Structural Engineering

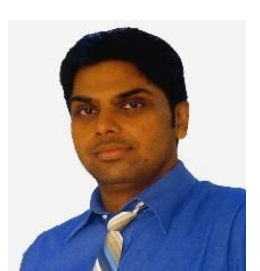

Dr Sandeep Singla

B. Tech degree in civil engineering in 2001 from Punjab Technical University, Jalandhar. M.Tech from Thapar Institute of Engineering \&Technology, Patiala in 2004 \& PhD degree from National Institute of Technology (NIT) Kurukshetra in 2018. Presently, he is working as Professor \& Head in Department of Civil Engineering, RIMT University,unjab, India.He has published more than 60 papers in nationaland international journals/conferences. He has guided more than 30 M.Tech thesis. Besides being member of board of studies in various universities, he is a life member of ISTE and also member of IEI. His researchinterests include environmenta engineering, waste management, concrete technology, artificial intelligence, remote sensing and GIS.

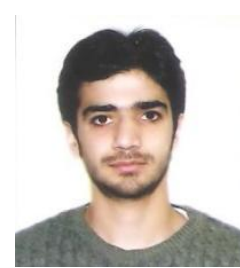

\section{Sualiheen Ahmad Pirzada}

Assistant Professor National Institute of Technology Srinagar. Former Assistant Professor Islamic University, Awantipora,Kashmir,India. B-Tech Civil Engineeringfrom Islamic University of Science and Technology Awantipora.M.Tech-

Transportation Engineering from Maharishi Dayanand University 
Rohtak, Haryana.He has worked in premier engineeringcolleges of the Valley of Kashmir as faculty.His interests include Highway Engineering,Road Construction Technology, Advanced Surveying,Geo Technical Engineering and Travel Demand Modelling.He has taken part in various conferences and camps related to the above mentioned subjects. 